ORIGINAL RESEARCH PAPER

\title{
THE NEW GASTRONOMIC PRODUCT: DRIED AND VACUUMED RAINBOW TROUT ROE
}

\author{
HÜLYA TURAN, BENGÜNUR ÇORAPCI, İRFAN KESKIN, BAYRAM KÖSTEKLİ* ASIYY \\ EYUBOGLU, CAN OKAN ALTAN, DEMET KOCATEPE
}

\author{
Department of Fish Processing Technology, Fisheries Faculty, Sinop University, Akliman \\ Sinop, Turkey \\ *corresponding author: bkostekli@ sinop.edu.tr
}

Received on 22 October 2020

Revised on 3 February 2021

\begin{abstract}
In this study, it was aimed to investigate that the effect of drying process on rainbow trout (Oncorhynchus mykiss Walbaum, 1792) roes in terms of the proximate composition, aw, pH, TVB-N, TBARs, microbiological counts and color parameters. Drying was lasted 42 hours including, 18 hours at $30^{\circ} \mathrm{C}$ and 24 hours at $45^{\circ} \mathrm{C}$. The dried fish roes were vacuum-packed (vacuum degree $0.02 \mathrm{MPa}$ ) and stored at $4^{\circ} \mathrm{C}$ for 90 th days. The crude lipid, crude protein, crude ash and moisture contents of fresh fish roe was $6.67 \%, 18.51 \%, 2,67 \%$, and $71.99 \%$, respectively. No change detected in terms of $\mathrm{a}_{\mathrm{w}}$ value in vacuum packed dried eggs between the first and 90 days $(\mathrm{p}>0.05)$. While the $\mathrm{pH}$ value of the fresh roe decreased with pretreatments and drying, TVB-N and TBARs value increased. At the end of the storage period, TVB-N value reached to $42.57 \mathrm{mgN} / 100 \mathrm{~g}$. The total mesophilic aerobe bacteria count of dried roes did not exceed the limit value at the end of the storage period. Total anaerobe mesophilic bacteria, Total Coliform, E. coli, $\mathrm{H}_{2} \mathrm{~S}$ producing bacteria (including $S$. putrefaciens) and Lactic acid bacteria counts of fresh and vacuumed dried roes were below detectable limit values $(<0.30$ $\log (\mathrm{FU} / \mathrm{g})$. In conclusion, it has been determined that vacuum-packed dried rainbow trout roes can be safely consumed for 60 days at $\pm 4^{\circ} \mathrm{C}$.
\end{abstract}

Keywords: rainbow trout, roe, caviar dried roe, vacuum package

\section{Introduction}

The rapidly increasing world population increases the need for nutrients, and especially the insufficiency of animal protein sources makes the protein resources valuable day by day. While achieving healthy and safe food is the primary goal of people, the demands of individuals in different beliefs and cultures are different. These social differences also increased the types of food sources, but primarily the

https://doi.org/10.35219/foodtechnology.2021.1.02 
limited number of protein sources increased the necessity of utilizing waste products, especially those that come from the main sources. In this context, considering seafood in terms of both health and taste, it is a food product with high preferability compared to other protein sources.

But being used as food, fish is also increasingly demanded use as feed. Nearly onethird of the world's wild-caught fish are "reduced" to fishmeal and fish oil, which are then used in feeds for livestock like poultry and pigs and feeds for farmed carnivorous fish (Delgado et al., 2003). This restricted people's access to seafood. In 2016, the apparent food fish consumption was only 20.3 kilograms per capita. Out of the 171 million tons of total fish production, about 88 percent or over 151 million tons were utilized for direct human consumption. The most preferred and highlypriced form of fish is live, fresh or chilled (45\% percent), followed by frozen (31\%), prepared and preserved (12\%) and cured (dried, salted, in brine, fermented smoked) (12\%) (FAO, 2018). It was reported that people in developing countries have a higher share of fish protein in their diets than those in developed countries (FAO, 2018). This led to an acceleration in aquaculture as well as wild-capture seafood in developing countries. Rainbow trout is one of the most produced cultured fish. The share of salmon and trout in world trade has increased strongly in recent decades, becoming the largest single commodity by value in 2016 (Köstekli et al., 2019). Also, the primary species are rainbow trout (103.192 tons in inland water, 9235 tons in the sea) aquaculture in Turkey in 2018 (TÜIK, 2020). These fish are usually exported live, fresh, chilled and frozen. Especially the fish that are filleted had more waste. The use of these products is important. One of the products that are produced as a surplus from trout is their roes. Rainbow trout (O. mykiss) is the main source of red caviar, which is extremely popular in the world (Özden et al., 2018). Although it is a waste product in Turkey, it is an expensive food with a gastronomic value processed in many countries. Among popular products, salted and frozen roe retained longer shelf life (Rao et al., 2015). Generally, salted fish roe is referred as "caviar" (Caprino et al., 2008, Özpolat and Patır 2009, İnanlı et al., 2010, Kaba et al., 2013, Özden et al., 2018, Rao et al., 2015). There are many studies in the literature on salting of different fish roes (Rodrigo et al., 1998, Caprino et al., 2008, Özpolat and Patır 2009, İnanlı et al., 2010, Patır et al., 2010, Çelik et al., 2012, İnanlı et al., 2019, Pourashouri et al., 2015, Chen et al., 2020). The salted fish roe can be used as a gastronomic product. This product, which has an intense and unique taste, can be used alone or added to salads. When used alone, it can be served as an alternative in gourmet restaurants. It increases both the flavor and nutritional quality of the product it is added to. Provides visual and nutritional saturation. It can also be used diluted in sauces to give flavor.

In this study, it was aimed to obtain a gastronomic product by drying the roes obtained as the production waste output of the rainbow trout (Oncorhynchus mykiss Walbaum 1792) aquaculture in Black Sea (Sinop region, Turkey). 


\section{Materials and methods}

\section{Materials}

In the study, a total of $12 \mathrm{~kg}$ of rainbow trout (Oncorhynchus mykiss Walbaum, 1792) (7 pcs) were used. The average length of trout is $44.93 \pm 0.93 \mathrm{~cm}$; the average weight is $1669.60 \pm 99.40 \mathrm{~g}$. Fish were obtained from a special aquaculture facility in Samsun-Turkey. Fish killed by hypothermia in the facility and placed in styrofoam boxes and delivered to the laboratory within 2 hours. The roes were taken out of the fish. Roe yield of fish is \%15.02 \pm 0.3 .

\section{Chemicals}

Ethyl alcohol, Boric acid, sulfuric acid (99.9\%), hydrochloric acid (37\%), Kjeldahl catalyst tablets, sodium hydroxide pellets, Brom-cresol: Green/Methyl Red mixed indicator solution, petroleum ether, 3,5-di-tert-4buthlyhydroxytoluene (BHT), Trichloroacetic acid (TCA), Glacial acetic acid, 2-Thiobarbituric acid were purchased from Sigma Aldrich (St. Louis, MO, USA). Buffered Peptone Water, Peptone from Casein, Cysteine chloride monohydrate, $\mathrm{NaCl}$, Plate Count Agar (PCA), Cetrimide agar, Iron agar, Baird Parker (BP) agar, Violet Red Bile Agar (VRBA), Man Rogosa Sharpe Agar (MRS), Potato Dextrose Agar (PDA) were purchased from Merck (Darmstadt, Germany) and Reinforced Clostridial Agar (RCA) were purchased from Oxoid Limited (UK).

\section{Preparations of dried roes}

Roes were washed several times in a 5\% salt solution until blood was completely removed (Figure 1) (a). Then it was kept in boiled cooled 4-5\% salt solution and its membrane was separated (Figure 1) (b). It was filtered and washed again and submerged in a $0.3 \%$ alcohol solution. Then, it had been kept on paper towels for 12 hours at $4^{\circ} \mathrm{C}$, after it was completely removed from the water, it was dried in the airconditioning cabinet (Delta NKD-250 Basic Model). Drying was lasted total 42 hours, including 18 hours at $30^{\circ} \mathrm{C}$ and 24 hours at $45^{\circ} \mathrm{C}$ and $42 \%$ humidity (Figure 1) (c-d). The dried fish roes were vacuum-packed (vacuum degree $0.02 \mathrm{MPa}, \mathrm{PA} / \mathrm{PE}$ vacuum bag $(30 \times 40 \mathrm{~cm}, 80 \mu$ thickness, oxygen transmission rate of $52.4 \mathrm{ml} / \mathrm{m} 2 /$ day at $23^{\circ} \mathrm{C}$ ) with vacuum packaging machine (Abant Group, MG42, Hellas, Sydney, Australia) and stored at $4^{\circ} \mathrm{C}$ for 90 days.

\section{Determination of proximate composition}

The roe's crude protein (by Kjeldahl method 952.52), crude ash (heating at $550^{\circ} \mathrm{C}$ ) and moisture (by air-drying method, 925.10) contents were analyzed by AOAC procedures (1995). Total crude fat contents of roes were analyzed by the soxtec method (AOAC 2005). The energy was calculated by applying the numbers of Atwater. The factors for protein and carbohydrate contents were $4 \mathrm{kcal} / \mathrm{g}$ and for the fat was $9 \mathrm{kcal} / \mathrm{g}$ (Falch et al., 2010).

\section{Determination of water activity, $\mathrm{pH}$, total volatile basic nitrogen, thiobarbituric acid reactive substance, and color analyses}

An automatic water activity machine (Novasina) was used for the analysis of water activity (aw). $\mathrm{pH}$, total volatile basic nitrogen (TVB-N mgN/100 g ) and thiobarbituric acid reactive substance (TBARs $\mathrm{mg} \mathrm{MDA} / \mathrm{kg}$ ) values of roes were 
determined according to the Manthey et al (1988), Ludorf and Meyer (1973) and Erkan and Özden (2008), respectively.

Color measurements were made with HunterLab Conica Minolta Color Meter device. Color measurement adopted by Commission Internationale de l'Eclairage (CIE) is used (Oleari, 2008). It was performed according to the Hunter colorimeter scale and there are three color values in the analyses; *a value is red or green, *b value is yellowness or blueness, The $* \mathrm{~L}$ value determines the degree of brightness between 0 (black) and 100 (white).

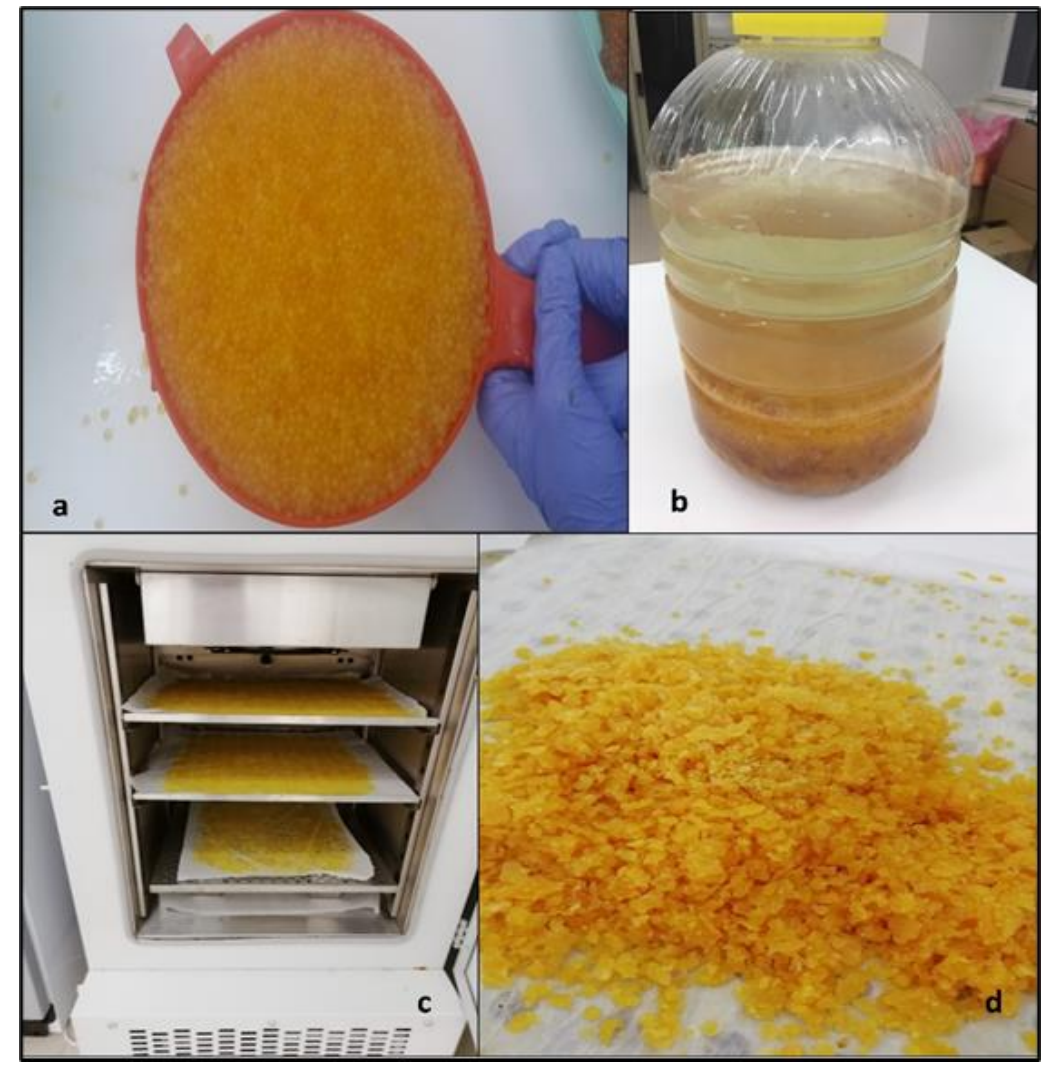

Figure 1. Processing steps in dried roe: a - washing, b - salting, $\mathrm{c}$ and d - drying.

\section{Microbiological analysis}

For the microbiological analysis except for total anaerobe bacteria, $10 \mathrm{~g}$ of the samples were diluted in $90 \mathrm{ml}$ buffered peptone water and homogenized in the stomacher for $2 \mathrm{~min}$. For total anaerobe bacteria special dilution mixture was used (Pepton from Casein (Merck 1.07213) 0.1\%; Cysteine chloride monohydrate (Merck 1.02839) $0.05 \% ; \mathrm{NaCl}$ (Merck 1.06404) 0.85\%). The total mesophilic aerobe bacteria (TMAB), total psychotropic aerobic bacteria (TPAB), total mesophilic anaerobic bacteria (TANB), total coliform (TC), total yeast and mold (TYM), E. coli, 
S. Aureus (Coagulase positive), Pseudomonas spp. loads were identified according to Halkman (2013). The $\mathrm{H}_{2} \mathrm{~S}$ producing bacteria (including Swenella putrefaciens) and lactic acid bacteria (LAB) were analyzed according to Kostaki et al. (2009).

\section{Statistically analysis}

The study was carried out in two replications and three parallel. A one-way analysis of variance was used to evaluate the differences in proximate, physical, chemical contents and microbiological loads using MINITAB 17.2.1.0. software program (Minitab Inc., State College, PA, USA). Differences between means was determined by Tukey's test (a level of $\mathrm{p}<0.05$ was used to establish significant differences among means).

\section{Results and discussion}

\section{Changes in the proximate composition of roes}

The proximate composition and energy values of fresh fish roe, dried roe on the first day and after 90 days of storage period was given in Table 1 .

Table 1. The proximate compositions and energy values of fresh and dried fish roe.

\begin{tabular}{rrrr}
\hline & \multirow{2}{*}{ Fresh roe } & \multicolumn{2}{c}{ Dried roe } \\
& & \multicolumn{1}{c}{ First day } & $90^{\text {th }}$ day \\
\hline Crude Lipid \% & $6.67 \pm 0.01^{\mathrm{c}}$ & $21.25 \pm 0.02^{\mathrm{a}}$ & $20.32 \pm 0.03^{\mathrm{b}}$ \\
Crude Protein \% & $18.51 \pm 0.04^{\mathrm{c}}$ & $54.13 \pm 0.00^{\mathrm{b}}$ & $57.44 \pm 0.03^{\mathrm{a}}$ \\
Crude Ash \% & $2.67 \pm 0.02^{\mathrm{c}}$ & $12.11 \pm 0.07^{\mathrm{a}}$ & $11.48 \pm 0.08^{\mathrm{b}}$ \\
Moisture \% & $71.99 \pm 0.02^{\mathrm{a}}$ & $12.37 \pm 0.05^{\mathrm{b}}$ & $10.58 \pm 0.06^{\mathrm{c}}$ \\
Carbohydrates \% & $0.16 \pm 0.00^{\mathrm{a}}$ & $0.14 \pm 0.00^{\mathrm{a}}$ & $0.19 \pm 0.02^{\mathrm{a}}$ \\
Energy (kcal/100g) & $134.75 \pm 0.07^{\mathrm{c}}$ & $408.31 \pm 0.18^{\mathrm{b}}$ & $413.34 \pm 0.26^{\mathrm{a}}$ \\
\hline
\end{tabular}

Mean values followed by different superscripts in the same column are significantly different $(\mathrm{P}<0.05)$

The crude lipid, crude protein, crude ash and moisture contents of fresh fish roe were $6.67 \%, 18.51 \%, 2.67 \%$, and $71.99 \%$, respectively. Özpolat and Patır (2009) reported the crude lipid, crude protein, crude ash and moisture contents of rainbow trout (Keban Dam, Elazığ, Turkey) roes as $11.1 \%, 23.2 \%$, 2\%, and $63.9 \%$, respectively. Similarly, İnanl et al. (2010) found that fish roes obtained from the same dam contained $11.70 \%$ crude lipid, $24.87 \%$ crude protein and $61.60 \%$ moisture. The fat and protein contents in roes obtained from rainbow trout was determined to be $9.14 \%$ and $24.32 \%$ (İnanl et al., 2019). The crude lipid and protein contents of the roes used in this study were lower than this literature. The high moisture content of the roes used in this study proportionally reduced the dry matter content. There are many factors that include the nutritional composition of fish roes, for example, fish species, fishing area, fishing region, season, spawning, (Bledsoe et al., 2003, Mahmoud et al., 2008, İnanl1 et al., 2019).

After the pretreatment and drying process applied to fresh roe, the content of crude oil, crude protein, and crude ash increased. Similar results had been reported by 
different researchers. It is said that especially the salting process applied to caviar causes dehydration and increases dry matter (Rodrigo et al., 1998, Pourashouri et al., 2015, Şengör et al., 2002). It was observed that crude ash and moisture content of the dried roes on day 90 decreased compared to day $0(\mathrm{p}<0.05)$. And it was determined that the processing and storage process had an effect on proximate composition $(p<0.05)$ except for carbohydrate values $(p>0.05)$. Decreasing moisture content along with pretreatments and drying also affected the energy amount of the roes. The maximum energy value $(413.34 \mathrm{Kcal} / 100 \mathrm{~g})$ was found in dried roe on the 90th day. The energy values of dried salted hake and ling roes were 328 and 320 Kcal/100g (Rodrigo et al., 1998).

\section{Changes in the water activity, $\mathrm{pH}, \mathrm{TVB}-\mathrm{N}$ and TBARs values of roes}

The water activity changes occurring in the product during the drying process and the fresh roes are given in Figure 2. The $a_{w}$ value of fresh roe was 0.980 , it decreased during the drying process.

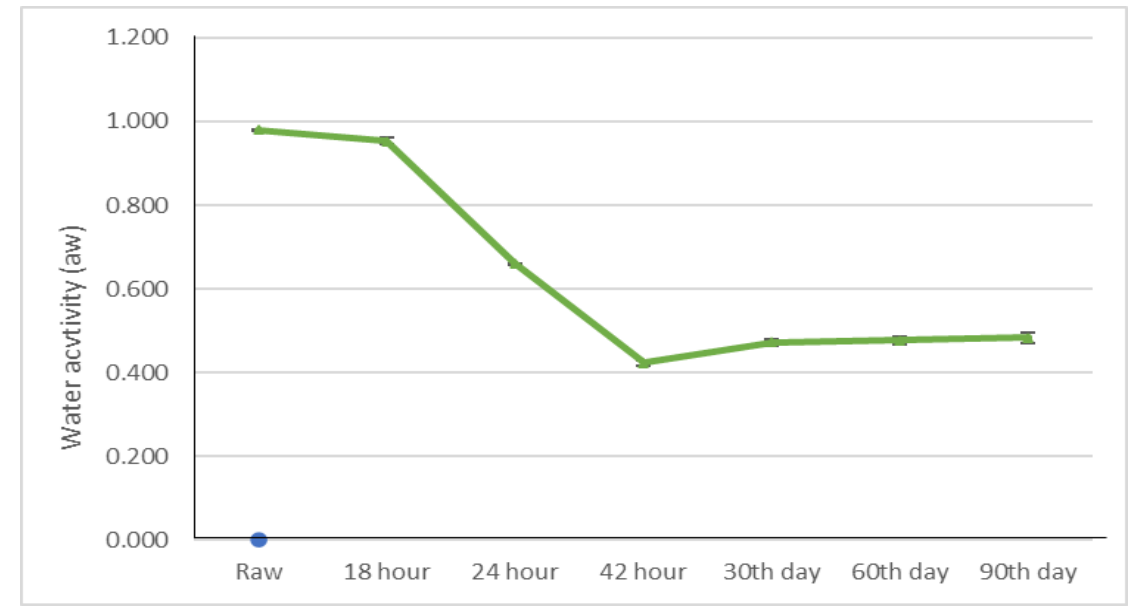

Figure 2. The water activity of fresh and dried roes.

No statistically significant change was observed in the water activity of the roe during the first 18 hours of drying. It was detected as 0.662 at the 24th hour and 0.424 at the 42 nd hour of the drying process $(p<0.05)$. No change in $a_{w}$ value was detected in vacuum packed dried eggs for 90 days $(p>0.05)$. It is seen that there is a lot of water loss during the drying period (Figure 2). The yield of the product obtained after drying was $26.11 \pm 1.21 \%$. A similar rate $(22.9 \%)$ was seen from dry salted roes (Özpolat and Patır, 2009).

The $\mathrm{pH}, \mathrm{TVB}-\mathrm{N}$ and TBARs values of roes are given in Table 2. The $\mathrm{pH}$ contents of different fish roe's varieties vary such as 7.49 in kutum roe (Rutilus frisii kutum) (Pourashouri et al., 2015), 5.79 in grey mullet roe (Çelik et al., 2012), 6.50 in fresh cod roe (Lapa-Guimarães et al., 2011), 6.55 in whiting roe (Kaba et al., 2013). The rainbow trout which caught from Atatürk Dam (Turkey) roe $\mathrm{pH}$ values were reported 
as 7.70 and 7.80 by Özpolat and Patır (2009) and İnanlı et al. (2010), respectively. The $\mathrm{pH}$ of the roes (6.57) used in the study is lower than the literature. The $\mathrm{pH}$ level of fresh caviar decreased with the effect of salt, alcohol, and drying used in pretreatments. It has been reported by different researchers that $\mathrm{pH}$ values of roes' decrease with salting (Pourashouri et al., 2015, Özpolat and Patır, 2009, İnanlı et al., 2010), ripening (Lapa-Guimarães et al., 2011) and smoking (Kaba et al., 2013). An increase in $\mathrm{pH}$ was observed during the storage period, and the $\mathrm{pH}$ measurement at first and third months were statistically similar ( $p>0.05)$.

Table 2. Changes in the $\mathrm{pH}, \mathrm{TVB}-\mathrm{N}$ and TBARs values of fresh and dried roes.

\begin{tabular}{ccccc}
\hline \multicolumn{2}{c}{ Storage period } & pH & TVB-N & TBARs \\
\hline & Fresh roe & $6.57 \pm 0.01^{\mathrm{c}}$ & $6.86 \pm 1.34^{\mathrm{d}}$ & $0.37 \pm 0.02^{\mathrm{d}}$ \\
& First day & $6.35 \pm 0.01^{\mathrm{d}}$ & $11.66 \pm 0.56^{\mathrm{c}}$ & $0.70 \pm 0.10^{\mathrm{c}}$ \\
& $\mathbf{3 0}^{\text {th }}$ day & $7.02 \pm 0.00^{\mathrm{a}}$ & $15.13 \pm 0.05^{\mathrm{c}}$ & $1.56 \pm 0.06^{\mathrm{a}}$ \\
& $\mathbf{6 0}^{\text {th }}$ day & $6.83 \pm 0.00^{\mathrm{b}}$ & $27.12 \pm 0.04^{\mathrm{b}}$ & $1.51 \pm 0.07^{\mathrm{b}}$ \\
& $\mathbf{9 0}^{\text {th }}$ day & $7.00 \pm 0.00^{\mathrm{a}}$ & $42.57 \pm 0.17^{\mathrm{a}}$ & $1.55 \pm 0.22^{\mathrm{a}}$ \\
\hline
\end{tabular}

Mean values followed by different superscripts in the same column are significantly different $(\mathrm{P}<0.05)$.

The volatile basic nitrogen includes several compounds such as; ammonia, monomethyl amine, dimethylamine and TMA, especially ammonia can be formed by bacterial or endogenous enzymatic activity (Lapa-Guimarães et al., 2011). In this study the fresh rainbow trout roe TVB-N values were detected as $6.86 \mathrm{mgN} / 100 \mathrm{~g}$, it increased with pretreatment process and drying (Table 2). Similar to this study results, Özpolat and Patır (2009) had reported the TVB-N values of fresh Rainbow trout roe as $6.10 \mathrm{mgN} / 100 \mathrm{~g}$. At the end of the storage period, it was exceeded the limit value (32-34mgN/100g) which stated by Alperden et al. (1981). It is known that TVB-N value of fresh roe varies according to the species $(10.9 \mathrm{mgN} / 100 \mathrm{~g}$ in fresh Kutum roe, $9.84 \mathrm{mgN} / 100 \mathrm{~g}$ in fresh whiting roe, $16.1 \mathrm{mgN} / 100 \mathrm{~g}$ in fresh cod roe and processing methods (Pourashouri et al., 2015, Kaba et al., 2013, LapaGuimarães et al.,2011).

TBARs value used in the measurement of lipid oxidation in seafood was found as $0.37 \mathrm{mgMDA} / \mathrm{kg}$ in fresh roe. Similarly, İnanlı et al. (2010) found that the TBARs of Rainbow trout roe was $0.02 \mathrm{mg} \mathrm{MDA} / \mathrm{kg}$. In the present study, the TBARs value of the fresh roe was increased with processing and storage periods. TBARs content of the product is $1.55 \mathrm{mgMDA} / \mathrm{kg}$ at the end of storage and this value was the same within the 30th day in statistically ( $>>0.05$ ). Also, Çelik et al. (2012) reported that the drying process increased the TBARs value of the red mullet roe.

\section{Changes in the microbiological composition of roes}

Microbiological analysis results of fresh roes and vacuum-packed dried roes are given in Figure 3. Fresh roes are highly susceptible to microbial spoilage due to high moisture, protein, and lipid contents (Rao et al., 2015). Total mesophilic aerobe 
bacteria (TMAB), total psychotropic aerobic bacteria (TPAB), total mesophilic anaerobic bacteria (TANB), total coliform (TC), total yeast and mold (TYM), E. coli, $S$. aureus (Coagulase positive), Pseudomonas spp., $\mathrm{H}_{2} \mathrm{~S}$ producing bacteria (including $S$. putrefaciens) and lactic acid bacteria (LAB) were analyzed. TANB, TC, E. coli, $\mathrm{H}_{2} \mathrm{~S}$ producing bacteria (including $S$. putrefaciens) and LAB loads of fresh and vacuumed dried roes were below detectable limit values $(<0.30$ LogCFU/g). At the beginning of the study, TMAB, TPAB, S. aureus (Coagulase positive), TYM and Pseudomonas spp. counts of fresh roes were $<0.30,2.11,<0.30$, $<0.30$ and $<0.30 \mathrm{LogCFU}$, respectively.

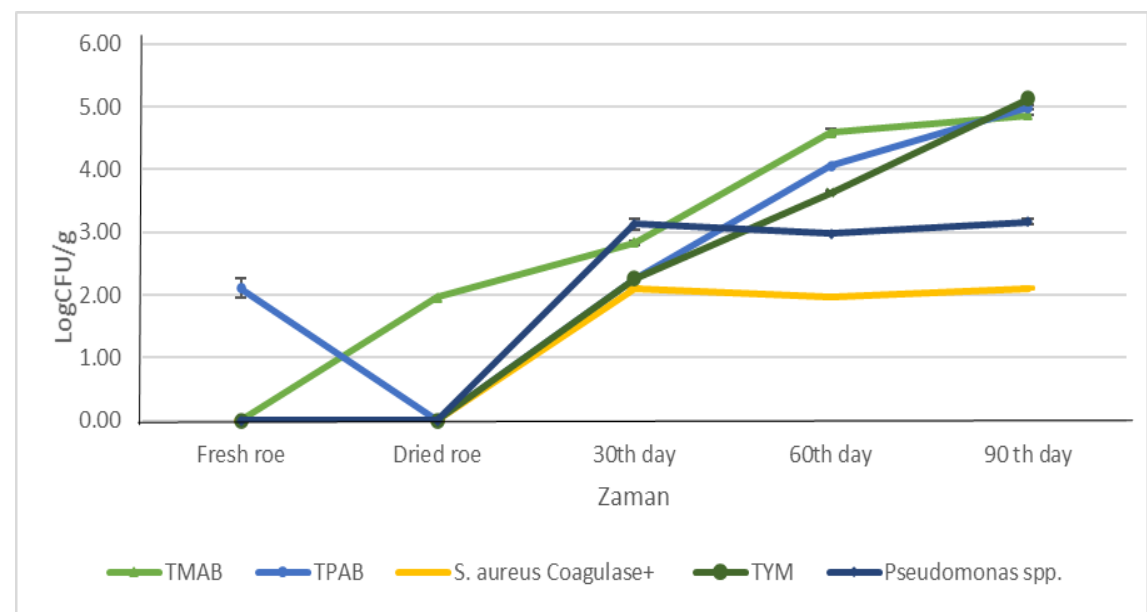

Figure 3. Changes in the microbiological composition of fresh and dried roes.

Patır et al. (2010) the TMAB, TC, E. coli, S. aureus and TYM load of fresh rainbow trout roes had reported as $2.05 \mathrm{LogCFU},<0.48 \operatorname{logEMS} / \mathrm{g}$, not detected, $<1$ and 0.97 $\log \mathrm{CFU}$, respectively. The fish used in the present study were harvested at the aquaculture facility under suitable conditions and brought to the laboratory by a cold chain. Microbiological results show that cross-contamination was very low during the harvesting and carrying process. With the pretreatments and drying applied, TMAB increased, TPAB decreased, and no change was observed in other microorganisms. TMAB counts of roes increased during storage $(\mathrm{p}<0.05)$. The TMAB count of roes did not exceed the ICMSF (1986) limit value for TMAB. While the $S$. aureus (Coagulase positive) counts of roes were minimum until 30th day ( $p>0.05$ ), it was detected as 1.96 and $2.11 \mathrm{LogCFU} / \mathrm{g}$ from the 30th day to the end of storage ( $p>0.05)$. Unlike the present study results, Patır et al. (2010) determined that $S$. aureus count of dried-salted and vacuumed rainbow trout roe was <1 LogCFU/g for 324 days. According to the Turkish Food Codex (2001), the limit of $S$. aureus counts in the ready to eat food is $1 \times 102 \mathrm{CFU} / \mathrm{g}$. At the end of the $90^{\text {th }}$ day, the count of $S$. aureus was close to this limit value. It may be due to the excess of salt used in this literature. Salt has been shown to effectively control microbial 
spoilage (Rao et al., 2015), and other processing methods applied can alter specific spoilage bacteria in the final product.

\section{Changes in the color parameters of roes}

The values of color parameters are shown in Figure $4 . \mathrm{L}^{*}$ is the luminous component that varies in the range of 0-100 (from black to white), $\mathrm{a}^{*}$ (green (-), red (+)) and $\mathrm{b}^{*}$ (blue (-), yellow (+)) are two chromatic (color) components with parameters ranging from -120 to +120 (Papadakis et al., 2000; Yam and Papadakis, 2004; Girolami et al., 2013). $\mathrm{L}^{*}, \mathrm{a}^{*}$ and $\mathrm{b}^{*}$ values of fresh roe were $60.08,1.25$ and 38.01 , respectively. The $\mathrm{L}^{*}$ values of fresh roes decreased with the drying process $(\mathrm{p}<0.05)$ and it increased after the 60th day. Similarly, the $b^{*}$ values of fresh roes decreased firstly $(p>0.05)$ and then increased after $60^{\text {th }}$ days.

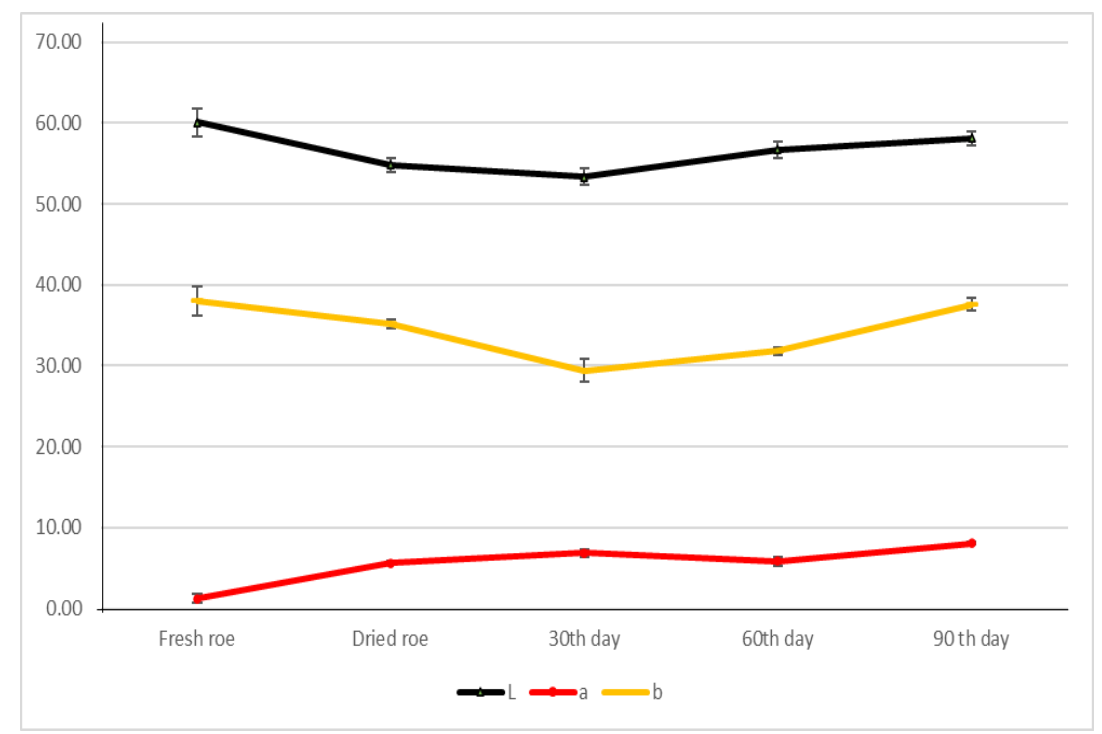

Figure 4. Changes in the color parameters of fresh and dried roes.

Celik et al. (2012) reported similar results for $\mathrm{L}^{*}$ and $\mathrm{b}^{*}$ values of dry salted flathead grey mullet. But the values of roes firstly increased with a dried process $(\mathrm{p}<0.05)$, however, the value of on the $30^{\text {th }}$ and $90^{\text {th }}$ days was statistically similar $(p>0.05)$. It is clear that the drying process considerably increased the redness value of the roe and caused fluctuation in brightness and yellowness values. $\mathrm{L}^{*}$ values of seafood have a positive relationship with moisture contents (Park 1995; Özkan et al., 2003; Bekhit et al., 2009). With the pretreatments and drying applied, approximately $10 \%$ lightness loss occurred in the roes $(p<0.05)$. Drying of the fish roe is a complex process as many variables are involved in the regulation of moisture migration and drying kinetics such as chemical composition, roe size, skein thickness and osmolality (Bekhit et al., 2009). 


\section{Conclusions}

In the present study, rainbow trout roes that are harvesting as waste products were pre-treated and dried under suitable humidity and temperature conditions. It has been determined that it is possible to store the new nutrient product, both chemically and microbiologically, under vacuum packaging for 60 days at $4^{\circ} \mathrm{C}$. In future studies, first of all, it should be aimed to bring a product with a very intense flavor to the industry, to combine it with flavor components and different technologies to reveal a product with a longer shelf life.

\section{Acknowledgments}

Thanks to "Kuzey Su Ürünleri, Samsun, Turkey" for the supplying the rainbow trout used in this study.

\section{References}

Alperden, I., Özay, G., Eyuboğlu, Y., Erdoğan, B. 1981. Use of Karbasan Product (leftover fish and oil). MAM publication number 81. Mbeae Press. Gebze Kocaeli. $111 \mathrm{p}$.

AOAC, (Association of Official Analytical Chemists) 1995.Official methods of analysis of the Association of Analytical Chemists International.

AOAC, (Association of Official Analytical Chemists) 2005. Official methods of analysis of the Association of Analytical Chemists International.

Bekhit, A.E.D.A., Morton, J.D., Dawson, C.O., Sedcole, R. 2009. Optical properties of raw and processed fish roes from six commercial New Zealand species. Journal of Food Engineering. 91(2), 363-371.

Bledsoe, G.E., Bledsoe, C.D., Rasco, B. 2003. Caviars and fish roe products. Critical Reviews in Food Science and Nutrition. 43, 317-356.

Caprino, F., Moretti, V.M., Bellagamba, F., Turchini, G.M., Busetto, M.L., Giani, I., Pazzaglia, M. 2008. Fatty acid composition and volatile compounds of caviar from farmed white sturgeon (Acipenser transmontanus). Analytica Chimica Acta. 617(1-2), $139-147$.

Çelik, U., Altınelataman, C., Dinçer, T., Acarlı, D. 2012. Comparison of fresh and dried flathead grey mullet (Mugil cephalus, Linnaeus 1758) Caviar by means of proximate composition and quality changes during refrigerated storage at $4 \pm 2$ C. Turkish Journal of Fisheries and Aquatic Sciences. 12(1), 1-5.

Chen, Y.W., Cai, W.Q., Shi, Y.G., Dong, X.P., Bai, F., Shen, S.K., Jiao, R., Zhang, X.Y., Zhu, X. 2020. Effects of different salt concentrations and vacuum packaging on the shelfstability of Russian sturgeon (Acipenser gueldenstaedti) stored at $4^{\circ} \mathrm{C}$. Food Control. $\mathbf{1 0 9}, 106865$.

Delgado, C., Wada, N., Rosegrant, M.W., Meijer, S., Ahmed, M. 2003. The future of fish: issues and trends to 2020. IFPRI Issue Brief 15. Washington, D.C. (USA): IFPRI

Erkan, N., Özden, Ö. 2008. Quality assessment of whole and gutted sardine (Sardine pilchardus) stored in ice. International Journal of Food Properties. 10(3), 421-434.

Falch, E., Overrien, I., Solberg, C., Slizyte, R. 2010. Composition and calories. Seafood and seafood product analysis. (Part III). 257-288. 
FAO. 2018. The State of World Fisheries and Aquaculture 2018 - Meeting the sustainable development goals. Rome. Licence: CC BY-NC-SA 3.0 IGO.

Girolami, A., Napolitano, F., Faraone, D., Braghieri, A. 2013. Measurement of meat color using a computer vision system. Meat Science. 93(1), 111-118.

Halkman, A.K. 2013. Food Microbiology II (Course Notes). Ankara University. Engineering Faculty. Department of food engineering. pp. 90, Ankara, Turkey.

ICMSF, 1986. International commission on microbiological specifications for foods. Sampling plans for fish and shellfish. In: Microorganisms in Foods. Sampling for Microbiological Analysis: Principles and Scientific Applications (Vol. 2, 2nd ed.). ICMSF (Ed.). Toronto, Canada: ICMSF, University of Toronto Press, p. 131.

İnanlı, A.G., Çoban, Ö.E., Dartay, M. 2010. The chemical and sensorial changes in rainbow trout caviar salted in different ratios during storage. Fisheries Science. 76(5), 879-883.

İnanlı, A.G., Çoban, Ö.E., Yılmaz, Ö., Özpolat, E., Kuzgun, N.K. 2019. Assessment of vitamin compositions and cholesterol levels of carp (Cyprinus carpio carpio) and rainbow trout (Oncorhynchus mykiss) caviars. Su Ürünleri Dergisi. 36(3), 1-1.

Kaba, N., Corapci, B., Eryasar, K., Karabek, H.N. 2013. Sensory, chemical and microbiological characteristics of canned smoked whiting roe pate. Journal of Food. 38(5), 259-266.

Kostaki, M., Giatrakou, V., Savvaidis, I.N., Kontominas, M.G. 2009. Combined effect of MAP and thyme essential oil on the microbiological, chemical and sensory attributes of organically aquacultured sea bass (Dicentrarchus labrax) fillets. Food Microbiology. 26(5), 475-482.

Köstekli, B., Keskin, I., Erdem, M.E. 2019. Determination of quality changes of hot smoked rainbow trout (Oncorhynchus mykiss Walbaum 1792) fillets kept in the deep freeze for different storage time periods. Fresenius Environmental Bulletin, 28(8), 5962-5972.

Lapa-Guimarães, J., Trattner, S., Pickova, J. 2011. Effect of processing on amine formation and the lipid profile of cod (Gadus morhua) roe. Food Chemistry. 129(3), 716-723.

Ludorf, W., Meyer, V. 1973. Fische und Fischerzeugnisse, Verlag Paul Parey, Germany bei A. W. Hayn's Erben. 17.

Mahmoud, K.A.S., Linder, M., Fanni, J., Parmentier, M. 2008. Characterization of the lipid fractions obtained by proteolytic and chemical extractions from rainbow trout (Oncorhynchus mykiss) roe. Process Biochemistry. 43(4), 376-383.

Manthey, M., Karnop, G., Rehbein, H. 1988. Quality changes of European catfish (Silurus glanis) from warm water aquaculture during storage in ice. International Journal of Food Science and Technology. 23(1), 1-9.

Oleari, C. 2008. Misurare il colore (2nd ed.). Milano: Hoepli Editore (Chapters 2 and 6). $139-244$

Özden, Ö., Erkan, N., Varlık, C. 2018. Havyar. Aydın Gastronomy. 2(2), 21-34.

Özkan, M., Kırca, A., Cemeroğlu, B. 2003. Effect of moisture content on CIE color values in dried apricots. European Food Research and Technology. 216(3), 217-219.

Özpolat, E., Patır, B. 2009. Gökkuşağı alabalığı (Oncorhynchus mykiss Walbaum, 1792) yumurtasından havyar yapımı ve bazı kimyasal parametreler üzerine araştırmalar. Süleyman Demirel Üniversitesi Eğirdir Su Ürünleri Fakültesi Dergisi, 5(1), 50-57. 
Papadakis, S.E., Abdul-Malek, S., Kamdem, R.E., Yam, K.L. 2000. A versatile and inexpensive technique for measuring color of foods. Food Technology (Chicago). 54(12), 48-51.

Park, J.W. 1995. Surimi gel colors as affected by moisture content and physical conditions. Journal of Food Science. 60(1), 15-18.

Patır, B., Özpolat, E., Şeker, P., Yalçın, H. 2010. Production of vacuum packaged caviar of rainbow trout (Oncorhynchus mykiss Walbaum, 1792) and changes in microbiological quality during storage. Firat University Veterinary Journal of Health Sciences. 25(1), 3136.

Pourashouri, P., Yeganeh, S., Shabanpour, B. 2015. Chemical and microbiological changes of salted Caspian Kutum (Rutilus frisii kutum) roe. Iranian Journal of Fisheries Sciences. 14(1), 176-187.

Rao, P.P., Balaswamy, K., Jyothirmayi, T., Karuna, M.S.L., Prasad, R.B.N. 2015. Fish roe lipids: composition and changes during processing and storage. In: Processing and Impact on Active Components in Food. Academic Press. pp. 463-468.

Rodrigo, J., Ros, G., Periago, M., López, C., Ortuño, J. 1998. Proximate and mineral composition of dried salted roes of hake (Merluccius merluccius, L.) and ling (Molva molva, L.). Food Chemistry. 63(2), 221-225.

Şengör, G.F.Ü., Cihaner, A., Erkan, N., Özden, Ö., Varlık, C. 2002. Caviar production from flathead grey mullet (Mugil cephalus, Lin. 1758) and the determination of its chemical composition and roe yield. Turkish Journal of Veterinary and Animal Sciences, 26 (1), 183-187.

TÜİK, 2020. Turkish Statistical Institute. Aquaculture Statistics. Ankara, Turkey, 2020.

Turkish Food Codex, 2001. Republic Turkey Ministry of Food, Agriculture, Turkish Food Codex, Microbiological Criteria Notification. No:02. 09.2001,24511. Official gazette, Ankara, Turkey.

Yam, K.L., Papadakis, S.E. 2004. A simple digital imaging method for measuring and analyzing color of food surfaces. Journal of Food Engineering. 61(1), 137-142. 